\title{
The Functionality and Comparisons of BSC and Alternative Theories in Organisations:
}

\section{Business Perspective}

Benneth C. Nwafor, PhD

London School of Science and Technology, United Kingdom

Hosein Piranfar, PhD

Amity University, London, United Kingdom

John Aston, PhD

Brunel University, London, United Kingdom

\section{Abstract}

The purpose of this research is to show the comparison of Resource-based view, Human capital, stakeholder as alternative theories and Balanced Scorecards (BSCs). ResourceBased View (RBV) appears to be limited with narrow implications as the strategic roles. RBV is forced on the internal organisation of a firm and it does not consider the external factors like the demand side of the market. A firm or an organisation may have the resources and the capabilities to gain a competitive advantage but still have no demand. RBV is not explicit on how particular market-based assets and capabilities contribute to generating and sustaining specific form of customer values. Accordingly, Human Capital theory (HC) assumes education increases productivity in the organisation, resulting in higher individual wages, but failed to provide adequate insight into the process through which education training are translated into higher wages. High level of educational attainment and quality may not potentially yield greater productivity and wages across the board. In the same vein, stakeholder theory has no learning and growth perspective required in the $21^{\text {st }}$ century business but provides managers with clear mission and facilitates decision making. Balanced Scorecards (BSCs) has four perspectives: Financial, Customer, Internal development and Learning and growth perspective. It sets priorities by identifying, rationalising and aligning initiatives. The broad aim of this study is to shed light on limitations of these theories. The paper intends to identify future research questions that would help to remove fundamental barriers to pave the way to the company-wide performance in Small Medium Enterprises (SMEs): does BSC or alternative theory add significant value to SMEs? If it does add value, how does it enhance the performance of SMEs in emerging economies?

Key words: resourced-based view; human capital; stakeholder; balanced scorecards; employees and performance. 


\section{Introduction}

BSC encompasses four perspectives of human and organisational development: the financial perspective, the customer's needs and desires, the internal processual development of organisations as the training and growth perspective of employees. The resource-based view is unique in terms of setting out what each company/organisation can achieve. It has been acknowledged that the resource-based view "is an efficiency-based view explanation of performance differences; it is concerned with Ricardian rents resulting from the scarcity of some resource-based view authors (Peteraf and Barney, 2003; Amit and Schoemaker, 1993; Peteraf 1993, Mahoney and Pandian, 1992; Conner, 1999; Barney, 1991; Wernerfelt, 1984). These authors recognise that the resource-based perspective and industrial organisational tools such as Porter's five forces model complement each otherinexplainingthesourcesoforganisation performance(Flore,2004). Theresource-based view is more oriented towards the longer term and may allow more fine-grained competitors analysis. It may, for instance be helpful in ascertaining the dangers of future competitive imitation through an analysis of the resources and capabilities of competitors. BSC is a performance measure that integrates both tangible and intangible factors. It provides a quick measure of organisational performance which is easy to understand and enhances communication with the key stakeholders groups from customers to employees (Mehmet and David 2007: p.9; Pier, 2005). The BSC is flexible enough to improve the strategies of non-profit organisations, and is sufficiently adaptable to fit the complexity of charitable missions. It has also been noted that BSC avoids placing unnecessary emphasis on financial measures, as the organisation respond to its demands in terms of quality and satisfaction (Mehmet and David 2007; Griffith and Alexander 2002).

The resource-based view suggests that firm resources provide the basis for strategy and that strategies should allow firms to best exploit resources relative to the competitive environment (Flore, 2004: p. 7). On the contrary, BSC offers four perspectives which improve stakeholder's superior resources and quasi-rents, i.e. the difference between the value of an asset in its first best use and its value in its next best use" (Flore, 2004). On the other hand, the BSC sets priorities by identifying, rationalizing, and aligning initiatives (Mehmet and David 2007: p.9). BSC allows executives to focus their attention on important matters, while front line workers can now understand the value of their employees and link their skills to the organisation's strategic objectives. Since BSC links strategy with resource allocation, according to Mehmet and David, it has a depoliticizing effect on the budgeting process because employees clearly understand strategic objectives. The BSC encourages proper accountability, particularly when it is connected to incentive plans.

Peteraf and Barney (2003: p. 311) state that "superior resources are more efficient in the sense that they enable firms to produce more economically and / or better satisfy 
customer's wants" Some authors such as Peteraf (1993) and Barney (1988 and 1993) support the equilibrium theory in which all phenomena should be represented as if in equilibrium. The BSC enables learning and continuous improvement by speeding up the learning process, especially when the results are compared to predictions. Employees will therefore be educated as to how the organisation measures success (Mehmet and David 2007; Inamdar and Kaplan 2002). Additionally, performance in organisations can be achieved in various ways. Human capital is another theory which suggest that people spend on themselves in diverse ways, and not purely for the sake of enjoyment.

\section{Brief Literature Review}

The resource-based view approach in performance management has stimulated discussion from various schools of thought and has also become a platform for organisations to have discussions about strategy. McCloskey (1985) argued that good science is a good conversation. The resource-based view is important for management because it generates useful conversation within strategic management. However, the research rejects the resource-based view approach because the operationalization of the resource-based view construct has been a major problem in the past (McGrath, 1996). Most published studies on the resource-based view use proxies from secondary data, such as data on constructs like physical resources. The resource-based view is seen as an alternative approach to understanding industrial organisations and their competitive strategies (Das and Teng 2000); but it cannot be used for statistical investigation due to the fact that it focuses on the various resources possessed by organisations or companies. However, the resource-based view does consider skilled labour as a resource, but it does not evaluate skills diversity which is a prime focus in Balanced Scorecards (BSC). The documentary evidence from the literature review has shown that the resource-based view is not central to employee functional skills diversity. Rather, it focuses its strength on the amount of resources companies acquire.

\section{Summary of Human Capital Theory}

This type of investment resonates with Mark's (1976) concept because it suggests investment in human capital development beyond consumptive expenditures; that is, expenditure beyond immediate gratification (Vainzey, 1962). Essentially, in human capital development, health and nutrition have been considered rudimentary parts of the progress. Schultz (1981) states that human capital investment includes health and nutrition, even though education is accepted as the number one concern for human capital investment in terms of empirical analysis. This is because it makes a recognised contribution to health and nutritional improvement (Schultz, 1963); and can be measured in monetary terms and in terms of years of tenure (Johnes, 1993). However, the literature has shown that forms of education can shape human capital development 
in organisations. In human capital theory, various forms of education that nurture and improve the economic capabilities of individuals and society have been observed. For example, Scott (1996: p. 341) acknowledged the development of "formalised education at primary, secondary and higher levels (Cohn and Geske, 1990), informal education at home and at work (Schultz, 1981), on- the - job training and apprenticeships (Mincer, 1994) and specialised vocational at secondary and higher levels" (Corazzini, 1967). Human capital theory focuses on the development of individuals for future gains, but it fails to articulate skills diversity amongst employees as a source of performance culture that could improve organisational performance.

\section{A brief account of Stakeholder theory}

The concept of stakeholder theory is based on moral values, relationships, property, ownership rights and free market economics. The stakeholder can be anyone who influences the organisation, or can be influenced. Examples include shareholders, employees and consumers; other examples are suppliers, government and communities. This suggests that since shareholders are the owners of publicly held companies, the managers of such companies are responsible for shareholder welfare and should act in the shareholder's best interest (Charnchai and James 2007). Some schools of thought have argued a contrary position and suggest that business is responsible for the well-being of all stakeholders, including customers, and communities, who are identified by their interests in the business. The argument and reason for this is that since managers are considered agents of all stakeholders, they should be responsible for protecting the rights of stakeholders and should consider the legitimate interests of the stakeholders when making business decisions. It has been said that stakeholder theories have not been empirically supported by conclusive performance evidence. Berman et al, (1999) found that the employees and the product safety/quality dimensions of stakeholder management were significantly related to corporate profitability, while the community, diversity and environment dimensions were not. Similarly, O'Toole (1999) found significant differences in the economic consequences of stakeholdercentered and conventional management approaches. These two competing normative theories have evolved in the literature to a great degree through philosophical debates and discussion (Charnchai and James 2007: p.381; Marcoux, 2003). The organisations/companies operating, particularly in Nigeria need to invest more in research and development so that they can find various performance measures that could be used to enhance employee skills diversity in organisations. 


\section{The alternative theories}

The alternative theories are: the Resource-Based View (RBV), Human Capital and Stakeholder theories.

The resource-based view is a theory that focuses on the competitive advantage of a firm on the application of its tangible or intangible resources at the firm's disposal. The research has seen the resource-based view as an alternative approach to understanding industrial organisations and their competitive strategies. The resource-based view is a theory which states that a firm is equivalent to a broad set of resources that it owns, unlike traditional industrial organisation economics, which rely so much on analyses of the competitive environment. The resource-based view focuses on the analysis of various resources possessed by the competitive environment suggesting that the parameters of a firm's competitive strategy are critically influenced by its accumulated resources (Barney, 1991). In other words, what a firm possesses determines what it accomplishes. Similarly, a firm can accomplish its economic goals by investing in human capital; that is, the education and training undertaken by individuals or groups of workers.

The second alternative theory is human capital theory. This theory refers to the stock of knowledge, habits, social and personality attributes, including creativity, embodied in the ability to perform labour so as to improve economic value. The theory of human capital suggests that individuals and society derive economic benefits from investments in people. Human capital expenditure theory significantly differentiates human capital expenditure from consumptive expenditure; that is, those providing few benefits beyond immediate gratification. In human capital theory, education consistently emerges as the prime human capital investment for empirical analysis. The reason is that education is perceived to contribute to health and nutritional improvements. Therefore, human capital requires an investment in education to be able to maximize shareholder wealth.

Shareholder theory holds that managers primarily have a duty to maximize shareholder interest in ways acceptable to law or social values. In other words, the essential ideology of a shareholder is based on property and ownership rights and free market economics. The ideology of shareholder value governs the decision making of managers. Stakeholder theory helps managers to set priorities amongst stakeholders, more specifically placing shareholders above other stakeholders. The ideology of shareholder value affects managerial decision-making in stakeholder moral dilemmas. This is notably complicated when the decision outcome affects different stakeholders. In stakeholder theory, there is also the likelihood of participants' decision outcomes to increase profits at the expense of suppliers. 


\section{The relevant areas in the alternative theories}

The relevant aspect of the resource-based view is that its supports the idea that an organisation's competitive advantage is defined by a bundle of unique resources and relationships. The understanding of diversification strategy is enhanced in this sense since the resource-based view argues for relatedness within an organisation. Sustainable differences in organisation profitability that cannot be attributed to industrial differences can be better explained by the resource-based view. The resource-based view has become relevant to analyses of sustainable competitive advantage. Similarly, these vital aspects of the resource-based view could be found in human capital theory. Human capital theory is important to the 'know how' of the work force that increases the productivity of each worker. The relevant aspect of human capital theory is that investments can be made in human beings, as well in physical capital which yields a future stream of returns. The process of investing in human capital normally takes much longer than that of physical capital. Most often it takes approximately eighteen years of formal education to achieve. Investment in human capital can include formal education, on the job training, informal education, life experiences, and learning by doing. Some activities in organisations that increase human capital include acquiring health care, offering additional education and providing information on job possibilities. In addition, individual organisations make human capital investments based on dividends or returns. In the same vein, a firm or an organisation requires a manager to look after its equity. Therefore, stakeholder theories provide guidelines for managers in their decision making.

The ideology of shareholder value is relevant in an organisation because it governs the decision making of managers in three ways as follows:

- Shareholder ideology helps managers to set priorities among stakeholders, more specifically placing shareholders above other stakeholders.

- It gives managers, professional and perhaps, moral legitimacy to make decisions in favour of shareholders when managers face stakeholder dilemmas.

- It impairs the managerial decision-making process. Drucker (1954) notes that the decision-making process consists of defining and analysing the problem then developing alternative solutions, selecting the most beneficial alternative, and converting the decision into action.

The ideology of shareholder value serves as a perceptual filter and leads managers to frame problems around conflicts of interests between shareholders and stakeholders. Stakeholder theory, the resource-based view and human capital development relate to each other, and to BSC in some ways. 
How do these alternative theories relate to each other and to the Balanced Scorecard

The BSC integrates intangibles in its approach and incorporates traditional approaches and off-balance sheet factors such as intangible assets into its four perspectives. BSC relates to resource-based view theory in the area of intangible assets, which includes information, knowledge, and dynamic capabilities. Human capital theory deals with long-term investment on human capital, for example, education and job training. The resource-based view suggests that the amount of resources a firm/an organisation holds or invests determines the returns that firm can expect. Accordingly, BSC relates to resource-based view theory in the area of intangibles, which includes information and dynamic capabilities. BSCs offer learning and growth perspectives which enhance development and improve on-the-job training and human capital. BSC relates to stakeholders since it tends to answer the question: how should we appear to our stakeholders? Realistically, stakeholder theory deals with property and ownership as well as customers and employees. Similarly, BSC has a financial perspective that improves stakeholder returns or dividends. Accordingly, human capital theory focuses on the training of individuals for future gain, while BSC focuses on internal processes or people's prospects. This dimension helps organisations to embark on exploration and exploitation. Human capital theory emphasizes that the amount of resources invested in developing human capital determines how viable the firm/organisation can be. These four theories relate to customer and employees, resources and returns, and investments in human capital.

\section{The comparison of Resource-based view, Human capital, Stakeholders and BSC theories}

Resource-based view, human capital and stakeholders theories provide a useful platform to gain sustainable competitive advantage, however, there are limitations in these theories which BSC offers more essential framework on enhancing employees' skills diversity and performance in the organisations (Nwafor, 2019). 


\begin{tabular}{|c|c|c|c|}
\hline Theories & Purpose & Comparison & Impact \\
\hline $\begin{array}{l}\text { Resource-based } \\
\text { view }\end{array}$ & $\begin{array}{l}\text { Resource-based view } \\
\text { can be used as a strategy } \\
\text { route in the growth of a } \\
\text { firm/an organisation's } \\
\text { strategy since it identifies } \\
\text { characteristics which } \\
\text { can create competitive } \\
\text { advantage for the } \\
\text { organisation such as } \\
\text { value, rareness and } \\
\text { competitive superiority. } \\
\text { Resource-based view } \\
\text { seemed to be more } \\
\text { implicit in the approach } \\
\text { of the question of } \\
\text { the process by which } \\
\text { competitive advantage } \\
\text { was created and there is } \\
\text { notangible translationfor } \\
\text { operating organisations. } \\
\text { Resource-based view } \\
\text { appears to be limited } \\
\text { with narrow implications } \\
\text { as the strategic roles. RBV } \\
\text { management seems to } \\
\text { be a process rather than } \\
\text { from the operational } \\
\text { functions of the } \\
\text { organisation's resources. } \\
\text { Resource-base view does } \\
\text { not have the definition } \\
\text { of customer value that } \\
\text { can be processed within } \\
\text { the organisation to } \\
\text { successfully leverage } \\
\text { resources to achieve } \\
\text { sustainable competitive } \\
\text { advantage. }\end{array}$ & $\begin{array}{l}\text { The RBV theory did } \\
\text { not cover an empirical } \\
\text { study of measuring } \\
\text { the performance } \\
\text { properly; as a result, } \\
\text { the heterogeneity of } \\
\text { organisations composing } \\
\text { a homogeneous } \\
\text { sample is hard or even } \\
\text { impossible to ascertain. } \\
\text { The resource-based view } \\
\text { is focused on the internal } \\
\text { organisation of a firm } \\
\text { and it does not consider } \\
\text { the external factors like } \\
\text { the demand side of the } \\
\text { market. For example, a } \\
\text { firm/an organisation may } \\
\text { have the resources and } \\
\text { the capabilities to gain a } \\
\text { competitive advantage } \\
\text { but still have no demand. } \\
\text { The usefulness of } \\
\text { resource-based view } \\
\text { focuses more in } \\
\text { generating understanding } \\
\text { and providing a structure } \\
\text { for strategizing. It can } \\
\text { enable managers to } \\
\text { understand the kind of } \\
\text { resources that would } \\
\text { generate sustained } \\
\text { strategic advantages and } \\
\text { evaluate the full range of } \\
\text { resources an organisation } \\
\text { may possess but there } \\
\text { is no emphasis on how } \\
\text { to improve customer's } \\
\text { employees and internal } \\
\text { development. }\end{array}$ & 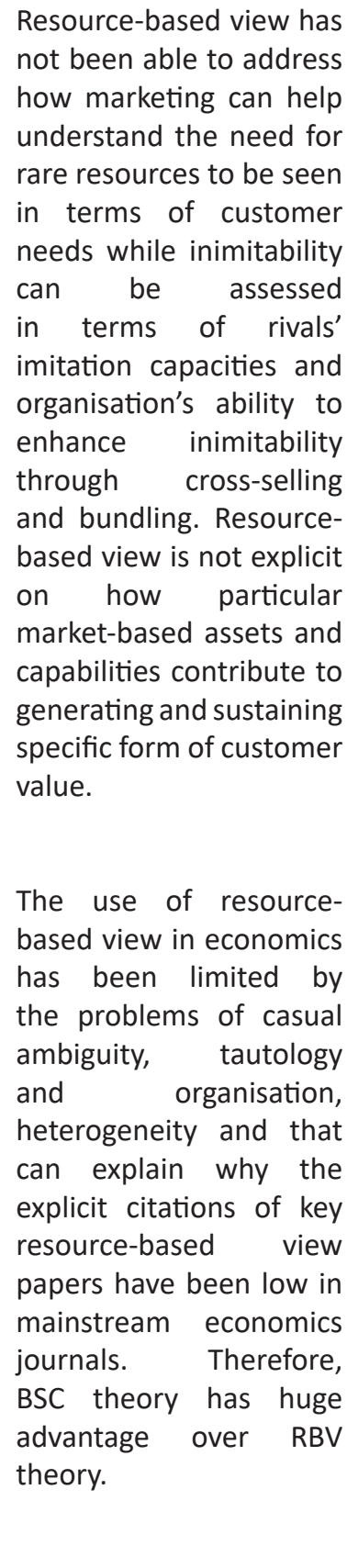 \\
\hline
\end{tabular}




\begin{tabular}{|c|c|c|c|}
\hline Human capital & $\begin{array}{l}\text { Human capital is } \\
\text { a framework that } \\
\text { re-examines the } \\
\text { relationships between } \\
\text { education economic } \\
\text { growth, and social well- } \\
\text { being. Human capital is } \\
\text { composite of individual } \\
\text { knowledge, skills and } \\
\text { experience. } \\
\text { Human capital theory } \\
\text { assumes education } \\
\text { increases productivity } \\
\text { in the organisation, } \\
\text { resulting in higher } \\
\text { individual wages, } \\
\text { but failed to provide } \\
\text { adequate insight into the } \\
\text { processes through which } \\
\text { education training are } \\
\text { translated into higher } \\
\text { wages. }\end{array}$ & $\begin{array}{l}\text { One major disadvantage } \\
\text { of human } \\
\text { Capital theory is the } \\
\text { assumption. It assumes } \\
\text { education increases } \\
\text { productivity at work } \\
\text { place and resulting } \\
\text { higher wages. } \\
\text { Human capital did not } \\
\text { provide enough insight } \\
\text { into the parameters or } \\
\text { processes through which } \\
\text { education and training } \\
\text { would be translated } \\
\text { into higher wages. It } \\
\text { also does not really } \\
\text { consider customers. The } \\
\text { application of human } \\
\text { capital assumes that } \\
\text { high level of educational } \\
\text { attainment and quality } \\
\text { will potentially yield } \\
\text { greater productivity and } \\
\text { wages across the board. } \\
\text { Essentially, considering } \\
\text { that education will } \\
\text { improve human capital } \\
\text { in this manner is a } \\
\text { gross mistake because } \\
\text { the process of human } \\
\text { capital formation varies } \\
\text { for individual and } \\
\text { groups. This theory does } \\
\text { not consider internal } \\
\text { process development or } \\
\text { customer perspective. }\end{array}$ & $\begin{array}{l}\text { People understand } \\
\text { reasons and tackle } \\
\text { quality and development } \\
\text { differently; also } \\
\text { education in one context } \\
\text { may proof ineffective in } \\
\text { another. For example, } \\
\text { the investment required } \\
\text { achieving a desired } \\
\text { result in urban schools } \\
\text { and universities are } \\
\text { completely different } \\
\text { from those in suburb } \\
\text { areas because of the } \\
\text { unique characteristics of } \\
\text { their student population. } \\
\text { Humancapitaltheoryfails } \\
\text { to consider: gender, race } \\
\text { and class discrimination } \\
\text { in education. } \\
\text { Every individual has } \\
\text { the right to be treated } \\
\text { equally by being } \\
\text { given fair and equal } \\
\text { opportunity. Human } \\
\text { capital theory has no } \\
\text { such plan on employees } \\
\text { and organisations. } \\
\text { Human capital has no } \\
\text { proper perspective } \\
\text { for accountability, } \\
\text { particularly when } \\
\text { it connected to manager } \\
\text { or employee incentives; } \\
\text { BSC does. }\end{array}$ \\
\hline
\end{tabular}




\begin{tabular}{|c|c|c|c|}
\hline Stakeholders & $\begin{array}{l}\text { The philosophy of the } \\
\text { shareholder's approach } \\
\text { tends to increase the } \\
\text { organisation's value } \\
\text { by enhancing firm's } \\
\text { earnings, increasing } \\
\text { the market value of } \\
\text { corporation's shares } \\
\text { and increasing also the } \\
\text { frequency or amount of } \\
\text { dividend. Shareholder } \\
\text { value approach provides } \\
\text { managers with clear } \\
\text { mission and it facilitates } \\
\text { decision making. The } \\
\text { theory also emphasized } \\
\text { that managers should } \\
\text { strive to maximize } \\
\text { shareholders value and } \\
\text { by doing so helps the } \\
\text { organisation to maximize } \\
\text { social welfare. } \\
\text { Shareholder value } \\
\text { analysis considers } \\
\text { the interest and the } \\
\text { advantage of the } \\
\text { shareholders, before } \\
\text { it makes any decision. } \\
\text { It provides a long term } \\
\text { financialview on which to } \\
\text { base strategic decisions. }\end{array}$ & $\begin{array}{l}\text { It mandates the } \\
\text { organisation to focus } \\
\text { on the future and its } \\
\text { customer, in particular } \\
\text { the value of future } \\
\text { cash flow. However, } \\
\text { disadvantages of the } \\
\text { shareholder value } \\
\text { analysis and estimation } \\
\text { of future cash flows can } \\
\text { be extremely difficult to } \\
\text { complete accurately. This } \\
\text { can lead to misleading } \\
\text { figures forming the basis } \\
\text { of strategic decisions. } \\
\text { This does not consider } \\
\text { customers perspective. } \\
\text { Development and } \\
\text { implementation of the } \\
\text { system can be long and } \\
\text { complex. Management } \\
\text { of shareholder value } \\
\text { requires more complete } \\
\text { information than } \\
\text { traditional measures. } \\
\text { Stakeholder ideas are } \\
\text { too narrow to be used or } \\
\text { adopted into any modern } \\
\text { organisation. It has no } \\
\text { perspective that can } \\
\text { improve } 21^{\text {st }} \text { century's } \\
\text { organisation as BSC does. }\end{array}$ & $\begin{array}{l}\text { Shareholders theory has } \\
\text { no learning and Growth } \\
\text { perspective required in } \\
\text { the } 21^{\text {st }} \text { century business. } \\
\text { Shareholders theory } \\
\text { has no such plan on } \\
\text { employees. Shareholders } \\
\text { theory does not provide } \\
\text { proper perspective for } \\
\text { accountability. } \\
\text { It does not increase } \\
\text { the credibility of } \\
\text { management. }\end{array}$ \\
\hline
\end{tabular}




\begin{tabular}{|c|c|c|c|}
\hline BSC & $\begin{array}{l}\text { The BSC concept was } \\
\text { basically launched as a } \\
\text { measure to assess the } \\
\text { operations of financial } \\
\text { and nonfinancial } \\
\text { assets of companies/ } \\
\text { organisations. It is simply } \\
\text { a tool that measures } \\
\text { tangibles and intangibles } \\
\text { assets in the day - to } \\
\text {-day operations in } \\
\text { the organisations. BSC } \\
\text { identify new business } \\
\text { opportunity in the } \\
\text { organisations using four } \\
\text { perspectives. } \\
\text { BSC has financial } \\
\text { perspective which } \\
\text { allows organisations to } \\
\text { exceed growth in key } \\
\text { segments. It concerns } \\
\text { how an organisation } \\
\text { should appear to their } \\
\text { stakeholders. } \\
\text { perspective includes } \\
\text { the main objectives } \\
\text { of the organisation } \\
\text { and shareholders } \\
\text { satisfaction. BSC uses } \\
\text { financial perspective } \\
\text { to increase sales, less } \\
\text { spending and increase } \\
\text { shareholders value. } \\
\text { This ideas are achieved } \\
\text { when customer's value } \\
\text { creation and proposition } \\
\text { is improved, since the } \\
\text { customer's transactions } \\
\text { are the only activity that } \\
\text { increase the sales. }\end{array}$ & $\begin{array}{l}\text { The BSC is using } \\
\text { customer perspective } \\
\text { to equip organisation in } \\
\text { building strong customer } \\
\text { relationships and product } \\
\text { values; create new } \\
\text { product and improve } \\
\text { organisational culture } \\
\text { and structure. This } \\
\text { perspective considers } \\
\text { primarily the desires } \\
\text { of their customers. It } \\
\text { has customer value } \\
\text { proposition that explains } \\
\text { how the organisation } \\
\text { can attract, retain and } \\
\text { maintain relationship } \\
\text { with other customers. } \\
\text { BSC is very explicit in its } \\
\text { customer perspective } \\
\text { than RBV, Human Capital } \\
\text { and Shareholders theory. } \\
\text { BSC has internal } \\
\text { perspective development } \\
\text { that improves research } \\
\text { and development } \\
\text { process. This dimension } \\
\text { enables an organisation } \\
\text { to focus more on what } \\
\text { business the organisation } \\
\text { must excel at. This } \\
\text { perspective covers } \\
\text { the transaction of the } \\
\text { strategic objectives } \\
\text { that are recorded in the } \\
\text { customer perspective. } \\
\text { These perspectives of } \\
\text { BSC theory seem to } \\
\text { have better values over: } \\
\text { RBV, Human capital and } \\
\text { another perspective that }\end{array}$ & $\begin{array}{l}\text { Learning and Growth } \\
\text { perspective deals } \\
\text { with development } \\
\text { of new ideas, skills } \\
\text { and inventions. This } \\
\text { perspective tackles } \\
\text { questions such as how } \\
\text { do we sustain ability } \\
\text { to change and improve } \\
\text { our organisations? BSC } \\
\text { is a theory that explains } \\
\text { what the organisation's } \\
\text { goals for different } \\
\text { constituents should } \\
\text { be and will highlight } \\
\text { appropriate measure for } \\
\text { which targets should be } \\
\text { developed. This is not the } \\
\text { case of other alternative } \\
\text { theories mentioned } \\
\text { in this research. BSC } \\
\text { appeared to have no } \\
\text { class discrimination, } \\
\text { gender or race prejudice; } \\
\text { it considers skills and } \\
\text { improves organisations. } \\
\text { mot been successful in a } \\
\text { small medium enterprise } \\
\text { (SME). } \\
\text { identifying, rationalising, } \\
\text { and aligning initiatives. } \\
\text { It enables learning and } \\
\text { continuous improvement } \\
\text { by speeding up the } \\
\text { learning process, } \\
\text { especially when the } \\
\text { actual result is compared } \\
\text { to predictions employees } \\
\text { will be thoroughly } \\
\text { educated as to how the }\end{array}$ \\
\hline
\end{tabular}




\section{Conclusion and limitations}

Resource-based view, human capital and stakeholders' theories provide a useful platform to gain sustainable competitive advantage, however, there are limitations in these theories which BSC offers more essential framework on enhancing employees' skills diversity and performance in the organisations (Nwafor, 2019). The strategic roles of RBV seems limited and, it does not have clear definition of customers values like BSCs which explicitly demonstrated customers values in its "customers perspectives" (Kaplan and Norton 2001).

The resource-based view is focused on the internal organisation of a firm and it does not consider the external factors like the demand side of the market. For example, a firm/an organisation may have the resources and the capabilities to gain a competitive advantage but still have no demand. However, RBV contributes greatly to firms/companies by analysing and interpreting their internal resources, it has also been useful in emphasizing resources and capabilities that could formulate strategy to improve sustainable competitive advantages. Similarly, Human capital did not provide enough insight into the parameters or processes through which education and training would be translated into higher wages. It also does not really consider customers.

Human capital has no proper perspective for accountability, particularly when it connected to manager or employee incentives, though these stocks of values: knowledge, social and personality attributes are needed to improve economic values. Shareholders theory has no learning and Growth perspective required in the $21^{\text {st }}$ century business. Shareholders theory has no such plan on employees. The shareholder value analysis and estimation of future cash flows can be extremely difficult to complete accurately and this can be one of its major limitation.

BSC has financial perspective which allows organisations to exceed growth in key segments and internal perspective development that improves research and development process. BSC also has Learning and Growth perspective that deals with development of new ideas, skills and inventions.

\section{Future research questions}

- Firstly, what are the roles of the BSCs and alternative theories within Small Medium Enterprises (SMEs)?

- Secondly, is there a shortfall in the use of the BSC concept and alternative theories as a means to improve SMEs and performance?

- Thirdly, does BSC add significant value to SMEs? If it does add value, how does it enhance the performance of SMEs in emerging economies?

- Fourthly, has BSCs and alternative theories recorded significant progress in the SMEs? 


\section{Bibliography}

1. Mehmet, C. K. and David, Fall 2007. A Balanced Scorecards Application in Health care: A case study: Journal of health care Finance.

2. Amit, R. and schoemaker, P. J. H. 1993. Strategic assets and organisational rent. Strategic Management Journal, 14: 33-46.

3. Barney, J. 1991. Firm resources and sustained competitive advantage. Journal of Management, 27:99.

4. Berman, S. L., Wicks, A. C., Kotha, S. and Jones, T. M. 1999. Does stakeholder orientation mather? The relationship between stakeholder management models and firm performance. Academy of Management Journal, 42: 488-507.

5. Charnchai, T. and James, G. P. 2007. Shareholder value ideology, Reciprocity and decision making in moral dilemmas. Journal of management issues, 19, N0. 3, pp. 379-396.

6. Conner, K. R. 1999. A historical comparison of resource-based value theory and five schools of thought within industrial organisation economics: Do we have a new theory of the firm? Journal of Management, 17: 124-154.

7. Corazzini, A. J. 1967. When should vocational education begin? The Journal of Human Resources, 2, 41-50.

8. Das, T. K. and Teng, B. 2000. A Resource theory of strategic Alliances. Journal of management, 26, N0. 1, 3161.

9. Drucker, P. 1954. The practice of Management. New York, NY: Harvard Business Press.

10. Flore, B. 2004. A resource-based approach to performance and competition. An overview of the connections between resources and competitions. IAG working paper.

11. Griffith, J. and Alexander, J. 2002. Measuring Comparative Hospital Performance. Journal of Healthcare Management No 47. 1: 41-47.

12. Kaplan, R. S. and Norton, D. P. 2001. 'Strategic performance measurements and management in non-profit organisations' Nonprofit management and leadership, 11(3), 353-370.

13. Mahoney, J. T., and Pandian, J. R. 1992. The resource-based view within the conversation of strategic management. Strategic Management Journal, 17: 549-569.

14. Mark, B. 1976. The Empirical Status of Human Capital Theory: A slightly Jaundiced Survey. Journal of Economic Literature, 14, N0 3 pp. 827-855.

15. McCloskey, D. N. The rhetoric of economics university of Wisconsin Press, Madison, WI, 1995. 
16. McGrath, R.G. 1996. The trouble with competence: opportunities and limitations in the adolescence of the resource-based view. Paper presented at the annual meeting of the Academy of management, Cincinnati, $\mathrm{OH}$.

17. Musaraj, A. (2011). Albania, the human factor and sustainable development: a lesson from the present. Academicus International Scientific Journal, 2(04), 35-41.

18. Musaraj, A. (2012). Tourism development, touristic local taxes and local human resources: A stable way to improve efficiency and effectiveness of local strategies of development. Academicus International Scientific Journal, 3(06), 41-46.

19. O'Toole, J. 1991. Do good, do well: The business enterprise trust awards. California management review 33: 9-24.

20. Peteraf, M. A. 1993. A resource-based view. Strategic Management Journal, 14: 179-191.

21. Peteraf, M. and Bergen, M. 2003. Scanning dynamic competitive landscapes: a market based and resource-based framework, Strategic Management Journal, 24, 1027-1041.

22. Schultz, T. W. 1981. Investing in People: The economics of education quality. Los Angeles: University of California Press.

23. Schultz, T. W. 1993. The economic value of education. New York: Columbia University Press.

24. Scott, R. S. 1996. Foundation of a field of Inquiry. American Educational Research Association. 66, N0 3, pp. 341-359.

25. Wernerfelt, B. A. 1984. A Resource-based view of the firm. Strategic Management Journal, 5, 171-180. 